\title{
The Financial Accounting Standards For Islamic Banking
}

\author{
Dr. Saad A. Alwabel \\ Department of Banking, \\ College of Economics and Administrative Sciences, \\ Al-Imam Muhammad Ibn Saud Islamic University
}

Saad A. Alwabel, PhD

Assistant Professor, Department of Banking, College of Economics and Administrative Sciences, Al-Imam Muhammad Ibn Saud Islamic University, Riyadh, Saudi Arabia.

Postal Address: Saad Ali Alwabel, Department of Banking, College of Economics and Administrative Sciences, Al-Imam Muhammad Ibn Saud Islamic University, 
P.O. Box 5701, Riyadh, Saudi Arabia.

Organizational Website: $\underline{w w w . i m a m u . e d u . s a}$

Email: sadalwabel@vahoo.co.uk

ملخص:

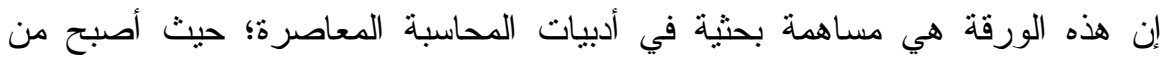

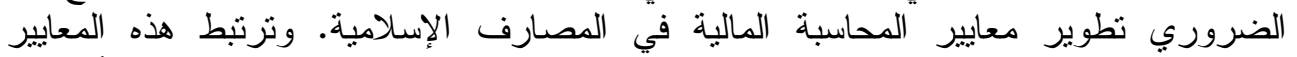

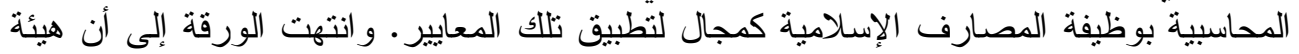

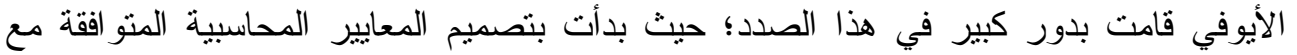

الثريعة منذ عام بو9 19؛ بهدف تطوير الفكر المحاسبي الإسلامي وتوحيد الممارسات المحاسبية

في المصارف الإسلامية.

الكلمات المفتاحية: الدحاسبة الإسلامية، المحاسبة الثقليدية، معابيير الدحاسبة المالية، هيئة المحاسبة

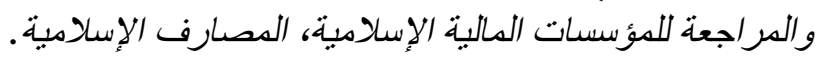

\begin{abstract}
:
This paper is a research contribution to the literature on contemporary accounting; where it became necessary to develop financial accounting standards in Islamic banks. The adoption of accounting standards depends on the function of Islamic banking where should that standards applied. Hence, the paper concludes that AAOIFI plays an important role in this regard. It designs the financial accounting standards which comply with Sharia. It started producing standards since 1993; in order to develop the Islamic accounting thought and harmonize the accounting practices of Islamic banking.
\end{abstract}

Key Words: Islamic Accounting, Conventional Accounting, Financial Accounting Standards, AAOIFI, Islamic Banking. 


\section{Introduction:}

Accounting is the science and the art of recording, classifying, analyzing data, presenting and interpreting information about business activities incurred by the firm during a certain period of time, so that its overall activity results and its financial position can be ascertained.

The aim of an accounting system is not to impose a purely technical system but a socio-technical activity or systems which reflect the characteristics of society in which decisions are being made.

As a financial intermediary, the basic mechanism of the Islamic banking is to accept deposits from surplus units on the liability side and offer financing on the assets side to the deficit units. The basic idea is to activate this mechanism on acceptable Islamic modes which preclude payment or receipt of interest and conform to the jurist rules of Sharia.

In 1991, Accounting and Auditing Organization for Islamic Financial Institutions (AAOIFI) was formed as a private sector standardsetting body in Bahrain with the aim of producing international accounting standards based on the Sharia precepts for Islamic banking and financial institutions. Total of 88 standards issued: 48 on Sharia, 26 accounting, 5 auditing standards, 7 governance, 2 codes of ethics. In addition, new standards are being developed and existing standards reviewed.

The axes of this paper consist of the following:

* Islamic Accounting Framework.

* AAOIFI Accounting Standards.

Islamic Financial Statements. 


\section{Islamic Accounting Framework}

\section{1- Accounting in Islamic Methodology}

Islamic accounting can be defined as the "accounting process" which provides appropriate information (not necessarily limited to financial data) to stakeholders of an entity which will enable them to ensure that the entity is continuously operating within the bounds of the Islamic Sharia and delivering on its socioeconomic objectives. Islamic accounting is also a tool, which enables Muslims to evaluate their own accountabilities to Allah (in respect of inter-human/environmental transactions) ${ }^{1}$.

The Main Objectives of Islamic accounting are ${ }^{2}$ :

7 Protecting funds intact, and declaring the ownership of all parties. Without writing (recording) transactions, we cannot count the creditness and debitness.

+ Ascertaining justice, and more convenient to prevent doubts.

$\$$ Helping in judgment between dealers. The judge man depends mainly on which is written down in records when he makes decisions

* Helping in ascertaining the results of business during a certain period of time, profit or loss.

+ Counting up the amount of zakat due at its time, and its distribution, between whom due.

$\neq$ Determining the ownership of partners in Islamic companies according to Islamic jurisprudence articles and rules.

Islamic accounting has some features which distinguish it from the

${ }^{1}$ Shahul Hameed bin Mohamed Ibrahim, Islamic Accounting - A New Push, Akauntan Nasional, Jan-Feb 2003.

${ }^{2}$ Hussien Shehata, Islamic Accounting Methodology, Website: www.darelmashora.com 
Conventional accounting. Amongst these features are the following ${ }^{3}$ :

$\forall$ It is based on the Believe Ethics such as the belief that Allah is the only owner of all things, the belief in the day after for accountability in front of Allah.

$\not$ It is based on Morals: such as: Allah fearing, honesty, trust, keeppromises, co-operation and forgiveness.

* Accounting principles are conducted from the sources of Islamic jurisprudence such as the Holy Quran and Sunnah. These principles are perfect, permanent and comprehensive.

+ Islamic accounting deals only with lawful transactions, and avoids evil and unlawful dealings.

7 Islamic accounting does stress on the behavioral aspects of the mankind working in the enterprise and motivates and incentives him towards straight path, according to Islamic jurisprudence.

* Islamic accounting is wider, it implies spiritual and secular aspects, it is applicable to the whole life.

\section{2- The Role of Islamic Civilization in Developing Accounting Tools}

The Islamic civilization has been established on the basis of justice between itself, and its bodies on one side, and between itself and the adjacent countries on the other hand, in addition to do justice among the citizens of the country. The Islamic civilization sees in accounting a tool to achieve the desired justice.

The tools which the Islamic Fiqh has innovated and used are distinguished with capacity and flexibility. They are tools used by the modern Islamic financial institutions (such as Modarabah, Morabahah, Ijarah, ...). Thus, this refers to their validity and accommodation with any time and place.

${ }^{3}$ Idem. 
According to Kantakji ${ }^{4}$, it is necessary to re-correcting the accounting history and do justice to the Arabs and Muslims by showing their participations and active role in this science. Instead of mentioning the beginning of history of accounting since the Italian Lucas Pacioli, we have to remember Al-Kalkashandi, Al-Nowayri, Al-Gazali, Abu-Ja'afar AlDemashki, Al-Mawardi, Al-Khuwarizmi and many other Muslim famous scientists who recorded accounting intellectually and practically since nearly (900) A.D. i.e. before Lucas Pacioli before (700) years at least. AlNowayri [(733) A.H.=(1355) A.D.] had written the first integral accounting reference in the human history.

Depending on the above-mentioned, some researchers ${ }^{\mathbf{5}}$, have got to the following recommendations:

Islamic organizations, academies and companies are to continue in rooting the Islamic accounting.

* The Muslim accountants have to go on in bringing out all the sides of knowledge in the Islamic accounting due to the need of the society of the Islamic works to an accounting reference agreeable with Allah's Sharia and helpful to them to carry out their work without legitimate violations. This may help in:

* Developing the trust of the users of financial data and statements in the information issued by the organizations that follow the Islamic accounting to encourage on investing their money according to the Islamic Sharia; thus, preventing the spread of non-trust among the users of the financial data and statements due to being doubted in containing false and misleading data and being unable due to containing data against

\footnotetext{
${ }^{4}$ Samer Kantakji, Islamic Accountancy Fiqh, Dar Arrissala, 2004, pp. 193-195, Website: www.kantakji.org

${ }^{5}$ Idem.
} 
the Islamic Sharia.

Stopping corruption by preventing bribery, exploiting people's money badly and preventing usury spread in all its kinds.

* Individuals' harmony with the financial policies of the state without the individual's conflict with his beliefs and with what should be applied; as by preventing the duality of the individual behavior and organizations by keeping two account-books to escape from taxes (in the positive economy) and to escape from paying "Zakat: alms" really.

$\not$ The possibility of applying the Islamic accounting in all its policies and terms through making use of the surrounding developments especially after founding the financial organizations and their remarkable success in different Islamic and non-Islamic parts.

$\$$ The necessity to teach the subject of Islamic accounting in the schools, institutes and colleges of economics, besides, other different subjects (from different international schools) taught at these bodies, nonetheless, the Conventional accounting scientists have recognized the increasing importance of Islamic accounting. "Choi and Mueller" have mentioned that "There is every reason to believe that in due course something labeled "Islamic accounting" will be identified and propagated in Islamic perspective is beginning to assert itself upon the international accounting scene. Its beginnings are modest, but it is fervor adamant. We believe that the Middle-East region will continue to make accounting news as the twenty-first century breaks" 6 .

\section{3- Islamic accounting VS Conventional accounting}

We can clarify the benefits and differences to be obtained from

${ }^{6}$ Choi, F. D.S. \& Mueller, G. G., International Accounting, New York: Prentice-Hall International Inc, $2^{\text {nd }}$ Edition, 1992, pp. 57; 65. 
applying the Islamic accounting systems ${ }^{7}$ :

$\forall$ The Islamic accounting depends on the Macro-Economy while the Conventional accounting depended on the Micro-Economy because it was interested in developing the economic unity interest itself disregarding the whole structure, so it was impossible to provide the desired benefits. Whereas, the Islamic Sharia has realized the social justice on the society level by applying "Zakah: Alms" system and on the family level by applying "Nafakah: Expenditure" and "Mawareeth: Legacy" systems. The change base from a collective duty to an individual duty forms the separate line (interface) between the economic unity accounting and social one.

\& The social accounting measurements and the environment came as supplementary lists in the Conventional accounting. However, it is incorporated originally in the Islamic accounting. For this reason the spread of accounting and finance rules in Fiqh books is an evidence. So, transactions are spread among people in all their applications and it seems difficult to separate between them and the legitimate rules and principles.

$1 *$ The Islamic Fiqh founded a deep-rooted market far away from cheating and its methods and void of illegal competition such as monopoly, distribution of goods and individuals' transfer from and into the market. That aims at determining the price depending on the just offer and demand by means of the competitive conditions reflected from the social, economic and political states of the countries. In case of any disturbance in determining the prices depending on other rules, the person in charge of the market situation should interfere to prevent one party from oppressing the

${ }^{7}$ Samer Kantakji, Op. Cit., pp. 189-190. 
other and should try to price in order to achieve justice again between supply and demand. Accounting is the helping tool in specifying and recognizing such states.

* The Islamic accounting does not recognize the separation between the general and professional morals that affect on the accountant's behavior. The source of morals is Sharia because man is man. Thus, it was stipulated in the "Lawmaker accountant" to be a free Muslim; however, freedom meant independence and non-alignment, these matters apply to the committees of putting standards and legitimate ones in the financial Islamic institutions. While the "accountant" working in the field of accounting application can disregard these two conditions along with adhering to the legitimate rules. In general, the accountant should be pious, accurate and of good morals. Professionally, he should have competence, efficiency, eloquence and reason agreeable with the job he does as its accountant and should adhere to the laws and organizing regulations besides his uprightness and non-alignment to any side.

Similarity and difference sides between Islamic and Conventional accounting determiners can be summarized as the following:

Table 1: Distinction between Islamic accounting and Conventional accounting

\begin{tabular}{|l|l|l|}
\hline Determiner & Islamic Accounting & $\begin{array}{l}\text { Conventional } \\
\text { Accounting }\end{array}$ \\
\hline Economic approach & Macro & Micro \\
\hline $\begin{array}{l}\text { Hypothesis in the } \\
\text { accounting thought }\end{array}$ & $\begin{array}{l}\text { Of a methodic origin. An } \\
\text { precedent of deductive } \\
\text { and experimental } \\
\text { methods. }\end{array}$ & $\begin{array}{l}\text { Setting off from a } \\
\text { methodic deductive } \\
\text { imitation for an } \\
\text { experimental reality } \\
\text { (experiment } \\
\text { rationalism) }\end{array}$ \\
\hline Assets' evaluation & Mithel price: The price & The price of the \\
\hline
\end{tabular}




\begin{tabular}{|c|c|c|}
\hline & of the Equal & historical cost \\
\hline $\begin{array}{l}\text { The approach in } \\
\text { specifying the revenue }\end{array}$ & Net of assets & $\begin{array}{l}\text { Net of revenue and } \\
\text { its costs }\end{array}$ \\
\hline $\begin{array}{l}\text { Does money have a } \\
\text { chronological value? }\end{array}$ & No & Yes \\
\hline $\begin{array}{l}\text { Is time of the } \\
\text { independent economic } \\
\text { resources? }\end{array}$ & $\begin{array}{l}\text { No, because its sale is } \\
\text { connected with } \\
\text { production, as settlement } \\
\text { sale. }\end{array}$ & $\begin{array}{l}\text { Yes, it can be sold } \\
\text { separately such as } \\
\text { usury. }\end{array}$ \\
\hline $\begin{array}{l}\text { Is usury interest } \\
\text { permissible? }\end{array}$ & No & Yes \\
\hline $\begin{array}{l}\text { Is there an accounting } \\
\text { period? }\end{array}$ & Yes & Yes \\
\hline $\begin{array}{l}\text { Accounting unity } \\
\text { concept }\end{array}$ & Private property theory & $\begin{array}{l}\text { Moral character } \\
\text { theory }\end{array}$ \\
\hline $\begin{array}{l}\text { The principle of } \\
\text { continuity depends on }\end{array}$ & $\begin{array}{l}\text { Violating of Islamic } \\
\text { Sharia }\end{array}$ & $\begin{array}{l}\text { Realizing the } \\
\text { income }\end{array}$ \\
\hline Financial statements & Real and cash & Cash \\
\hline $\begin{array}{l}\text { Economic events' } \\
\text { concept }\end{array}$ & $\begin{array}{l}\text { Financial and non- } \\
\text { financial }\end{array}$ & Financial \\
\hline $\begin{array}{l}\text { Are there taxes on } \\
\text { production? }\end{array}$ & No & Possible \\
\hline $\begin{array}{l}\text { Are there taxes on } \\
\text { sales? }\end{array}$ & No & Possible \\
\hline $\begin{array}{l}\text { Are there taxes on } \\
\text { income? }\end{array}$ & No & Possible \\
\hline $\begin{array}{l}\text { Taxes are calculated } \\
\text { on the basis of the net } \\
\text { of }\end{array}$ & $\begin{array}{l}\text { The wealth "Zakat: } \\
\text { Alms" }\end{array}$ & Income and capitals \\
\hline "Iktinaz: Saving"' & Forbidden & Possible \\
\hline $\begin{array}{l}\text { Liquidation upon } \\
\text { death is according to }\end{array}$ & "Mawareeth: Legacy" & Positive law \\
\hline $\begin{array}{l}\text { Recognizing the } \\
\text { revenue occurs on }\end{array}$ & Production & Sale \\
\hline $\begin{array}{l}\text { Profit and Loss } \\
\text { distribution happens } \\
\text { according to an } \\
\text { agreement }\end{array}$ & Without preaching Sharia & No matter \\
\hline $\begin{array}{l}\text { The capital is divided } \\
\text { into }\end{array}$ & Good and bad & $\begin{array}{l}\text { No difference with } \\
\text { reference to newly } \\
\text { money laundry. }\end{array}$ \\
\hline Capital nature & "Motakawem: Valuated" & All are valuated \\
\hline
\end{tabular}




\begin{tabular}{|c|c|c|}
\hline & $\begin{array}{l}\text { and "Non-Motakawem: } \\
\text { non-Valuated" }\end{array}$ & \\
\hline Assets are divided into & $\begin{array}{l}\text { Only the valuated one } \\
\text { divided to: "Keniah: } \\
\text { property" and "Trading } \\
\text { Assets" }\end{array}$ & $\begin{array}{l}\text { Fixed, current and } \\
\text { cash assets } \\
\text { regardless of their } \\
\text { nature. }\end{array}$ \\
\hline It is considered gaining & The legitimate only & Every income \\
\hline Profits are divided into & $\begin{array}{l}\text { Profit, "Faedah: interest } \\
\text { and yield", "Ghalah: } \\
\text { yield" }\end{array}$ & $\begin{array}{l}\text { Profit, capital and } \\
\text { accidental }\end{array}$ \\
\hline $\begin{array}{l}\text { The accountant's } \\
\text { leaving during the year }\end{array}$ & $\begin{array}{l}\text { Needs preparing "Irtifaa: } \\
\text { balance sheet" }\end{array}$ & $\begin{array}{l}\text { Does not need } \\
\text { anything (he } \\
\text { prepares a trial } \\
\text { balance) as an } \\
\text { opinion. }\end{array}$ \\
\hline $\begin{array}{l}\text { Mentioning non- } \\
\text { financial data }\end{array}$ & $\begin{array}{l}\text { Possible, they are } \\
\text { "Hawasel Madoumah: } \\
\text { dead results" }\end{array}$ & No \\
\hline Financial statements & $\begin{array}{l}\text { Every year and every } \\
\text { three years and are called } \\
\text { "Jaishiah statements" }\end{array}$ & Every year \\
\hline $\begin{array}{l}\text { The complementary } \\
\text { statements }\end{array}$ & $\begin{array}{l}\text { They are called } \\
\text { suggestions }\end{array}$ & $\begin{array}{l}\text { Complementary } \\
\text { statements }\end{array}$ \\
\hline Discount rate & $\begin{array}{l}\text { The lowest rate the } \\
\text { investor sacrifices to } \\
\text { leave his money }\end{array}$ & $\begin{array}{l}\text { It is the interest } \\
\text { price }\end{array}$ \\
\hline The accounting morals & The legitimate morals & $\begin{array}{l}\text { The professional } \\
\text { morals }\end{array}$ \\
\hline
\end{tabular}

Source : Samer Kantakji, Op. Cit., pp. 193-195.

\section{AAOIFI Accounting Standards}

\section{1- The Need of Islamic Accounting Standards}

Accounting Standards for financial reporting by Islamic financial institutions have to be developed because in some cases Islamic banking encounter accounting problems due to existing accounting standards such as IFRSs or local GAAP being developed based on conventional banking, conventional product structures or practices, and may be perceived to be 
insufficient to account for and report Islamic banking.

The Islamic accounting standards serve as a guideline that may reflect the unique characteristics of Islamic banking and become a useful tool to meet the various needs of Islamic banking. Currently, one of the major challenges facing Islamic banking lies in the preparation of the financial statements under different accounting standards and which may lead to problems of comparability, reliability and compliance level measurement. This has resulted in a heated debate among scholars which has hitherto translated to the evolving existing literature surrounding the interpretation of the level of compliance with the Islamic accounting standards.

We can clarify the need for harmonization of accounting practices of Islamic banking in the following ${ }^{8}$ :

$\$$ The need for an accounting standard is not very different from the need for any other kind of standards, whether standards for weights and measures, or standards for clothing sizes, grades of beef, or baseball statistics. The goal or objective of an Islamic accounting standard is to facilitate comparisons and thereby minimize the social and economic costs of assessing the alternatives with which one is faced in making rational decisions.

${ }^{8}$ See: Hamat, M., Accounting System; Need for Accounting Standards and the Implications of Islamic Banking on Current Tax Laws. Conference of Managing and Implementing Dual Banking System, Kuala Lumpur, 1994; Karim, R.A.A, International Accounting Harmonization, Banking Regulation and Islamic Banks; Karim, R.A.A, The Nature and Rationale of a Conceptual framework for Financial Reporting by Islamic Banks, Accounting and Business Research, 25 (100), 1995, pp. 285-300; Mirza, A.M. \& Baydoun, N., Accounting Policy Choice in a Riba-free Environment, Accounting, Commerce \& Finance: The Islamic Perspective Journal, Vol.4, Nos. 1 \& 2, 2000, pp. 30- 47; Pendlebury, M. \& Naser, K., The Influence of Islam on Bank Financial Reporting, International Journal of Commerce \&Management, 7 (2), 1997, pp. 56-83. 
+ Unless a proper disclosure with regard to the financial reporting, the underlying Sharia principles and the accounting methods adopted is made, the information contained in the financial statement will not be useful for a comparison of the performance of different Islamic banks. Inadequate disclosure of the underlying Sharia principles will subject the Islamic banking' activities to a lot of questions with regard to their Islamicity. Thus, the need for standard accounting practices in the reporting of Islamic banking' operations is very clear.

$\not$ The emergence of Islamic banking and financial institutions as relatively new organizations and the great challenge they face to successfully serve the societies in which they operate, have led them, together with specialists in Islamic Sharia and accounting, to seek the most appropriate means through which accounting standards could be developed and implemented in order to present adequate, reliable, and relevant information to users of the financial statements of such organizations. The presentation of such information is critical to the economic decision making process by parties who deal with Islamic banking and would also have a significant effect on the distribution of economic resources for the benefit of society.

$\forall$ The structure and processes of Islamic banking do not readily fit in with those of conventional universal banking, which combines both commercial and investment businesses. This seems to have resulted in supervisory bodies adopting different approaches to regulate Islamic banking. Such variations in the regulation of Islamic banking appear, in turn, to have resulted in Islamic banking adopting different accounting treatments for the same transaction. This rendered the financial statements of Islamic banking noncomparable. 
1 Another major problem in the accounting and operation of Islamic banking is the lack of precision in the application of the Sharia principle to Islamic banking. The Sharia does not refer directly to banking or its accounting, but to broad issues relating to the prohibition of the paying and receiving of riba, transactions relating to pork, gambling, speculation, etc. Therefore, for Islamic countries to operate, in a practical manner, the application of Sharia principles to the accounting and operations of Islamic banking is important.

$\not$ In regulating the financial reporting of Islamic banking, financial accounting plays an important role in providing the information which the users of the financial statements of Islamic banking depend on in assessing the bank's compliance with the precepts of the Sharia. However, to perform this role effectively, accounting standards need to be developed and complied with by Islamic banking. The development of such standards must be based on clear objectives of financial accounting and agreed upon definitions of its concepts.

\section{2- Background of the AAOIFI}

The Accounting and Auditing Organization for Islamic Financial Institutions (AAOIFI) is an Islamic international autonomous non-for-profit corporate body that prepares accounting, auditing, governance, ethics and Sharia standards for Islamic banking and the industry. Professional qualification programs (notably (Certified Islamic Public Accountant) CIPA, the Certified Sharia Adviser and Auditor "CSAA", and the corporate compliance program) are presented by AAOIFI in its efforts to enhance the industry's human resources base and governance structures.

As an independent international organization, AAOIFI is supported by institutional members ( 200 members from 40 countries, so far) including 
central banks, Islamic financial institutions, and other participants from the international Islamic banking and finance industry, worldwide.

AAOIFI has gained assuring support for the implementation of its standards, which are now adopted in the Kingdom of Bahrain, Dubai International Financial Centre, Jordan, Lebanon, Qatar, Sudan and Syria. The relevant authorities in Australia, Indonesia, Malaysia, Pakistan, Kingdom of Saudi Arabia, and South Africa have issued guidelines that are based on AAOIFI's standards and pronouncements.

AAOIFI standards are followed - as part of regulatory requirement or Islamic banking internal guidelines - in jurisdictions that offer Islamic finance across Middle East, Asia Pacific, South Asia, Central Asia, Africa, Europe, and North America; and Islamic Development Bank Group.

The objectives of AAOIFI are ${ }^{9}$ :

* To develop accounting and auditing thoughts relevant to Islamic banking;

7 To disseminate accounting and auditing thoughts relevant to Islamic banking and its applications through training, seminars, publication of periodical newsletters, carrying out and commissioning of research and other means;

$\not$ To prepare, promulgate and interpret accounting and auditing standards for Islamic banking;

$\Varangle$ To review and amend accounting and auditing standards for Islamic banking.

AAOIFI carries out these objectives in accordance with the precepts of Islamic Sharia which represents a comprehensive system for all aspects of life, in conformity with the environment in which Islamic banking have

${ }^{9}$ AAOIFI, website: $h$ ttp://www.aaoifi.com/aaoifi 
developed. This activity is intended both to enhance the confidence of users of the financial statements of Islamic banking in the information that is produced about these institutions, and to encourage these users to invest or deposit their funds in Islamic banking and to use their services.

\section{Figure 1: AAOIFI Structure}

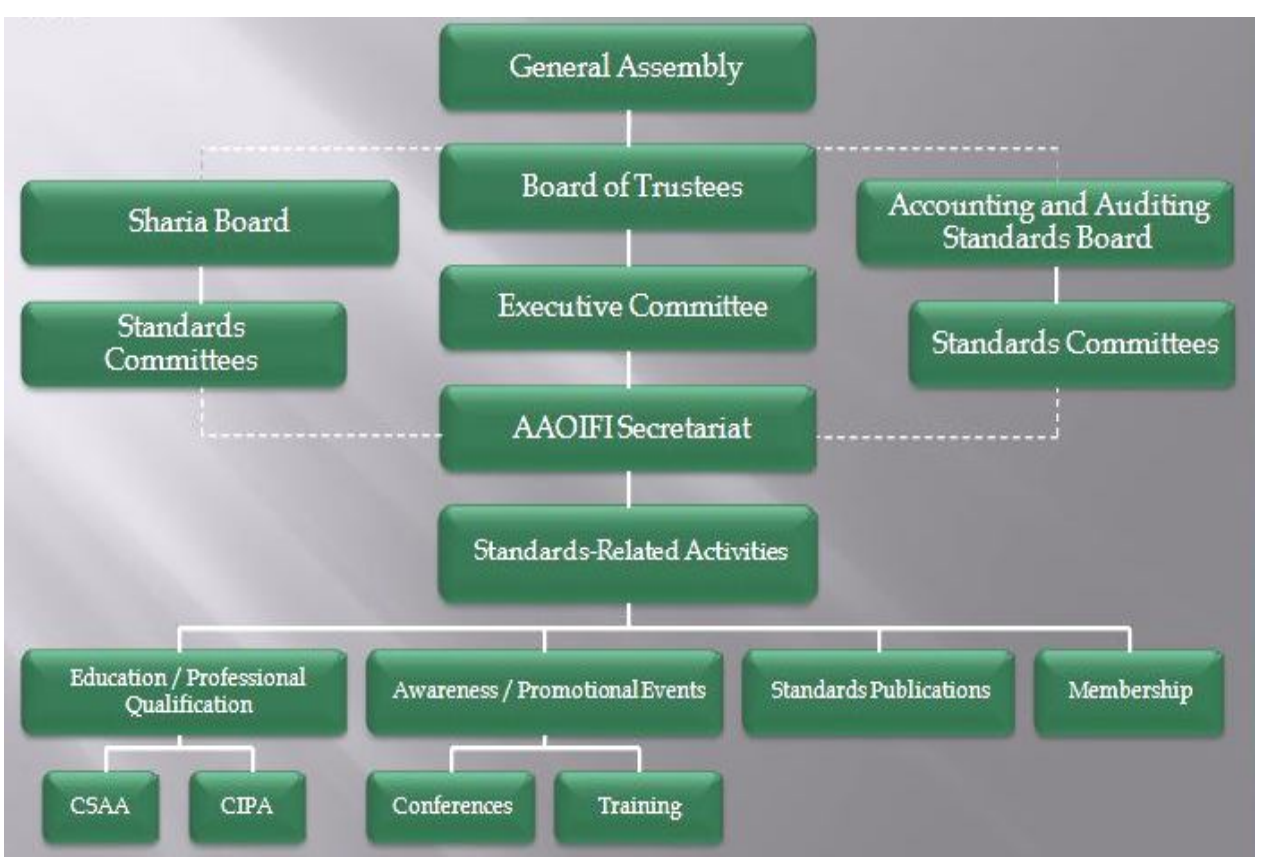

Source : AAOIFI, website: http://www.aaoifi.com/aaoifi

\section{3-AAOIFI's Standards}

AAOIFI standards have been developed in consultation with leading Sharia scholars, with several counties adopting them. Although AAOIFI standards are not binding on members, over the last few years the organization has made significant progress in encouraging the widespread adoption of the standards.

Prior to implementation of AAOIFI standards many financial institutions were operating under a "semi-regulated market"; where accounting policies were determined with the assistance of the bank's Sharia Supervisory Board (SSB). In addition, over this period, International Accounting Standards (IAS) or respective national accounting standards 
were followed by Islamic banking. Hence, the unique requirements of Islamic banking were not being met. To give two examples:

$\not$ Fiduciary risk: the Mudaraba contract places liability of the loss on the mudarib.

* Displaced commercial risk: where Islamic banking "smooth" the returns Investment Account Holders by varying the percentage of profit taken as Mudarib share.

As a result, with the support of banking authorities, AAOIFI standards were created. In an industry that is often quite fragmented, it is hoped that the development of AAOIFI standards will go a long way in promoting convergence in Sharia standards and leading to further growth in this nascent market.

AAOIFI started producing standards as early as 1993. Currently, AAOIFI has published 88 standards that comprises of 26 accounting standards, five auditing standards, seven governance standards, two ethics standards, and 48 Sharia standards ${ }^{\mathbf{1 0}}$.

The following accounting standards have been developed by AAOIFI:

1. Objective of financial accounting for Islamic banks and financial institution.

2. Concept of financial accounting for Islamic banks and financial institution.

3. General presentation and disclosure in the financial statements of Islamic banks and financial institution.

4. Murabaha and Murabaha to the purchase orderer.

5. Mudaraba financing.

6. Musharaka financing.

${ }^{10}$ Idem. 
7. Disclosure of bases for profit allocation between owners' equity and investment account holders.

8. Equity of investment account holders and their equivalent.

9. Salam and Parallel Salam.

10. Ijarah and Ijarah Muntahia Bittamleek.

11. Zakat.

12. Istisna'a and Parallel Istisna'a.

13. Provisions and Reserves.

14. General Presentation and Disclosure in the Financial Statements of Islamic Insurance Companies.

15. Disclosure of Bases for Determining and Allocating Surplus or Deficit in Islamic Insurance Companies.

16. Investment Funds.

17. Provisions and Reserves in Islamic Insurance Companies.

18. Foreign Currency Transactions and Foreign Operation.

19. Investments.

20. Islamic Financial Services Offered by Conventional Financial Institutions.

21. Contributions in Islamic Insurance Companies.

22. Deferred Payment Sale.

23. Disclosure on Transfer of Assets.

24. Segment Reporting.

25. Consolidation.

26. Investment in Associates.

Consequently, AAOIFI standards have introduced greater harmonization of Islamic banking practices across the world.

III. Financial Statements For Islamic Baking

\section{1- Functions of Islamic Banking}


AAOIFI attempts to come up with a conceptual framework for Islamic accounting or accounting for Islamic financial institutions under SFA2 which considers mixed bag consisting of quality characteristics, elements of financial statements and concepts rolled into one statement, much like the International Accounting Standards Board (IASB) framework.

The adoption of accounting standards depends on the function of business where should that standards applied. In Islamic banking there are four functions which are ${ }^{11}$ :

+ Investment Management is a function performs by banks based on either a Mudaraba contract or an agency contract. According to the Mudaraba contract, the bank receives a percentage of the returns only in case of profit. However, in case of loss the bank receives no reward for its effort and the provider of funds is allocated the losses. When Islamic bank invest funds (its own fund or holders funds) to conduct Murabaha contracts, ijarah, musharka, Mudaraba contracts, Salam or Istisna' contracts, formation of enterprises or the acquisition of controlling or other interests in existing enterprises, trading products, and investment or trading in publicly traded shares or real estate. These transactions report in balance sheet in assets side.

7 Another important function is investment which includes unrestricted and restricted mudaraba, both unrestricted and restricted mudaraba are represented in assets side too in balance sheet.

Beside that Islamic banking offer financial services based on an agency contract or a rental by using fee base such as, letter of guarantee, wire transfers.

$\not$ Finally, Islamic banking also offer social services for instance, Qard,

11 AAOIFI, Accounting and Auditing Standards for Islamic Financial Institutions, Manama, Bahrain, 2007, pp. 31-33. 
Zakat, charity fund.

Figure 2: Functions of Islamic Banking

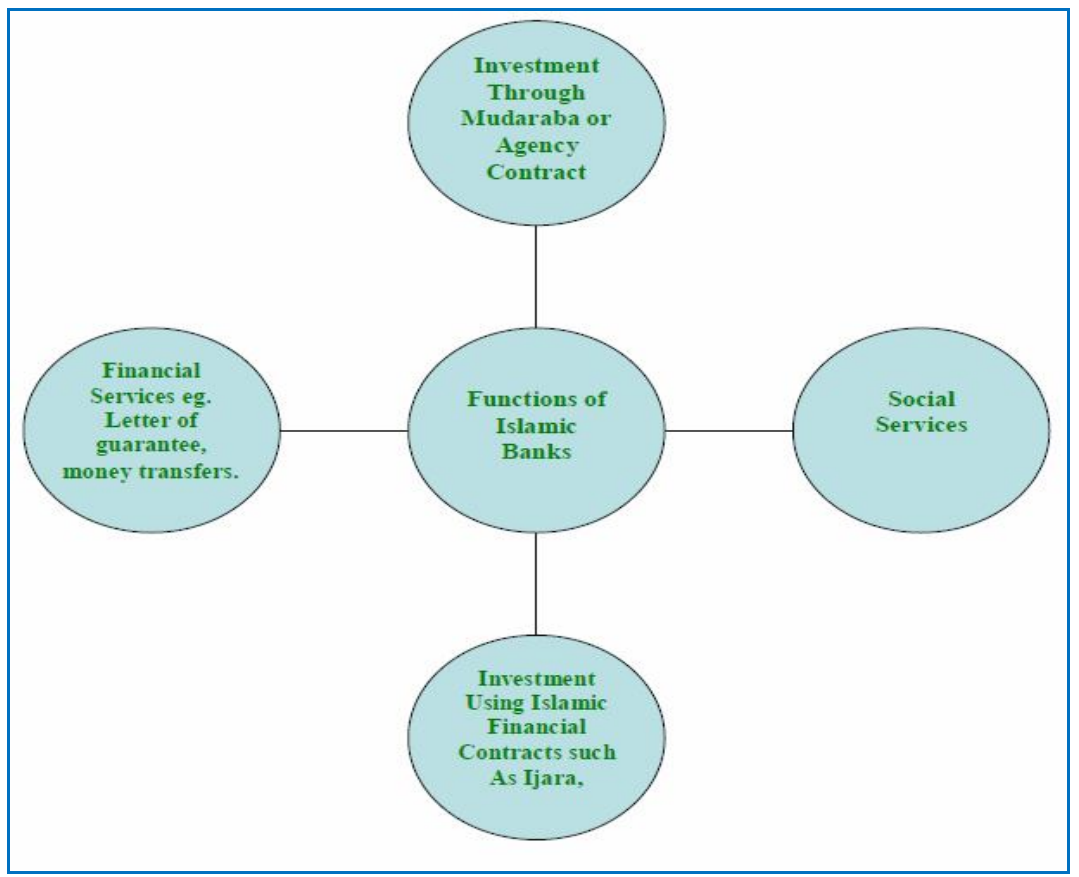

\section{2- Financial Statements of Islamic banking}

Conventional banks use four statements which are: balance sheet, income statement, cash flow, and statement of changes in owners' equity. SFA2 adds three statements to the conventional bank statements, these statements are: Statement of changes in restricted investments, statement of sources and uses of funds in the Zakat and charity fund, and Statement of Sources and uses of funds in the Qard fund ${ }^{12}$.

2-1- Balance Sheet: This statement should include the Islamic bank's assets, liabilities, equity of unrestricted investment account holders and its equivalents, and its owners' equity. Separate totals for assets, liabilities,

${ }^{12}$ Ibid, pp. 35-47. 
unrestricted investment accounts and their equivalents, and owners' equity must be provided:

Assets: An assert is any measurable thing that is capable to generate cash flows or other economic benefits in the future, individually or in combination with other assets, of which the Islamic bank has acquired the right to hold, use or dispose of, as a result of past transactions or events. For instance, Cash and cash equivalent, Receivables (Murabaha, Salam, Istisnaa), Investment securities, Mudaraba investment, Musharaka investment, Investment in other entities, Inventories, Investment in real estate, Assets acquired for leasing, Other investments (disclosure of their types), Fixed assets (disclosure of depreciation for significant asset types), and Other assets (disclosure of significant types).

* Liabilities: A liability is any measurable present bank's obligation to another party to transfer assets, extend the use of an asset, or provide services to that party in the future as a result of past transactions or events. The Islamic obligation must not be a reciprocal to an obligation of the other party to the bank. The balance sheet for Islamic bank must note these liabilities, Current accounts, saving accounts and other accounts with separate disclosure of each category, Deposits of other banks, Salam Payable, Istisnaa Payable, Declared but undistributed profits, Zakat and taxes payable, and other accounts payable.

\section{Equity of unrestricted investment account holders and their} equivalents: It refers to the amount of original funds received minus withdrawals or transfers to other accounts plus/minus shares in profits/losses. Unrestricted investment accounts and their equivalents are treated as elements of the financial position. This account is not considered a liability since there is no obligation on the bank to 
guarantee original principals except in cases of proven neglect, nor ownership equity because they do not enjoy voting right or entitlement to profits generated from the use of the bank's current accounts. Here, the unrestricted investment account holders and their equivalents should be disclosed, whether the bank acts as Mudarib or agent as well as separately disclosure of assets jointly financed by the Islamic bank and unrestricted investment account holders and those exclusively financed by the bank should be provided in supplementary notes.

* Owners' Equity: It is the amount remaining at the date of the statement of financial position, from the Islamic bank's assets after deducting the bank's liabilities, equity of unrestricted investments and their equivalents and prohibited earnings if any.

2-2- Income Statement: Income statement must include separate disclosures of investment revenues, expenses, gains and losses jointly financed by the bank and unrestricted investment account holders and their equivalents:

$\forall$ Revenues: Presented by increases in assets or decreases in liabilities due to investment by, or distribution to owners, deposits or withdrawals by unrestricted account holders or their equivalents, deposits or withdrawals by current or non-investment account holders or the acquisition of assets. This revenue should be recognized when it takes place, there are three conditions to recognize the revenue which are: the bank should have earned the right to receive revenue through a completely consummated process, an obligation must fall on another party to a remit a fixed or a determinable amount to the bank, and amount should be known and collectible.

* Expenses: It is gross decreases in assets or increases in liabilities 
resulting from the same sources as defined for expenses.

* Gain and losses: A gain is a net increase in net assets or from incidental legitimate reciprocal (e.g sale of assets not acquired for sale) or no-reciprocal transfers (donations), except for non-reciprocal transfers with equity owners or holders of unrestricted investment accounts or their equivalents. A loss is a net decrease in net assets or from incidental legitimate reciprocal and non-reciprocal transfers (e.g. penalties by Central Bank), except for nonreciprocal transfers with equity holders or holders of unrestricted investment accounts or their transfers. Gain and losses are recognized either when completion of a reciprocal or non-reciprocal transfer resulting in gain or loss, or sufficient evidence indicating reasonably measurable appreciation or depreciation in values of recorded assets or liabilities.

Return on unrestricted investment accounts: It is the share allocated to the holders of these accounts out of investment profits/losses as a result of their joint participation with the Islamic bank with the financing of investment transactions during the period covered by the income statement - not an expense (in case of profit) or revenue (in case of loss).

$\not$ Net income (net loss): It is the net increase (decrease) in owners' equity resulting from revenues, expenses, gains, losses, after allocating the return on unrestricted investment accounts and their equivalents, for the period. All legitimate changes in equity are included except those resulting from investment by owners and distributions to owners.

\section{2-3- Statement of retained earnings or changes in owners' equity:}

Statement of changes in owners' equity: Basic elements are net 
income (loss), investment by and distribution to owners (nonreciprocal transfers). Investment by owners is the amount of increase in owners' equity, while distribution to owners is decrease in owners' equity: The former results from the transfer of assets, or performance of service, or the assumption, or payment by owners of an obligation of Islamic bank for the purpose of increasing their equity in the bank. The latter results from transfer of assets by the Islamic bank to owners, or performance of services, or assumption or payment of the owners for the purpose of reducing their equity in the bank (e.g dividends).

- Statement of retained earnings: Basic elements are net income (loss), dividends, and transfers to other owners' equity accounts. The latter is a decrease retained earnings resulting from their transfer to legal or other reserves or to the owners' capital accounts.

2-4- Statement of cash flows: The statement should disclose the net increase (decrease) in cash and cash equivalent during the given period and the balance of cash and cash equivalent at the beginning and end of the period. As regards transactions and other transfers that do not require payment or receipt of cash and cash equivalent should be disclosed (e.g bonus shares, or acquisition of assets in exchange for shares in the equity of the bank).

\section{2-5- Statement of changes in restricted investment and their equivalent:}

Restricted investment accounts and their equivalents are based on restricted Mudaraba which are not assets for bank; therefore, it should be reported in annual report off-balance sheet. The statement must show deposits and withdrawals by holders of restricted investments and their equivalent as of a given date. With regards of disclosure, the statement should include: 
+ Balance of restricted accounts at the beginning of the period, with separate disclosure for the part of the balance which results from revaluation of restricted investment accounts to their cash equivalents where applicable.

* Number of investment units in each of the investment portfolios and the value per unit at the beginning of the period.

* Deposits received or investment units issued during the period.

$\$$ Withdrawals or repurchase of units during the period.

* Bank's share in investment profit as Mudarib or fixed fee as investment agent.

$*$ allocated overhead expense, if any.

* Restricted investment accounts profits/losses during the period with separate disclosure of the part resulting from revaluation to cash equivalents where applicable.

\& Number of investment units in each of the investment portfolios at the end of the period and the value per unit.

\section{2-6- Statement of sources and uses of funds in the Zakat and Charity}

Fund: Zakat is a fixed obligation calculated by reference to net assets that have appreciated or have the capacity to appreciate in value over a specific period of time except for assets acquired for consumption or used in production. In the case of a limited liability company, Zakat should be based on the company's net assets, and the total amount be divided between owners who should then their Zakat obligations personally. Otherwise, the company should pay out Zakat on behalf of its owners, if it is so authorized. The bank may also act as an agent of Zakat or other charitable contributions for its various accounts' holders and other parties.

2-7- Statement of sources and uses of funds in the Qard Fund: Qard 
is a non-interest bearing loan allowing borrower to use the loaned funds for a specific period of time such that the same amount of loan should be returned to lender at the end of the period - a means of achieving social objectives.

Figure 3: AAOIFI's Recommended Set of Financial Statements

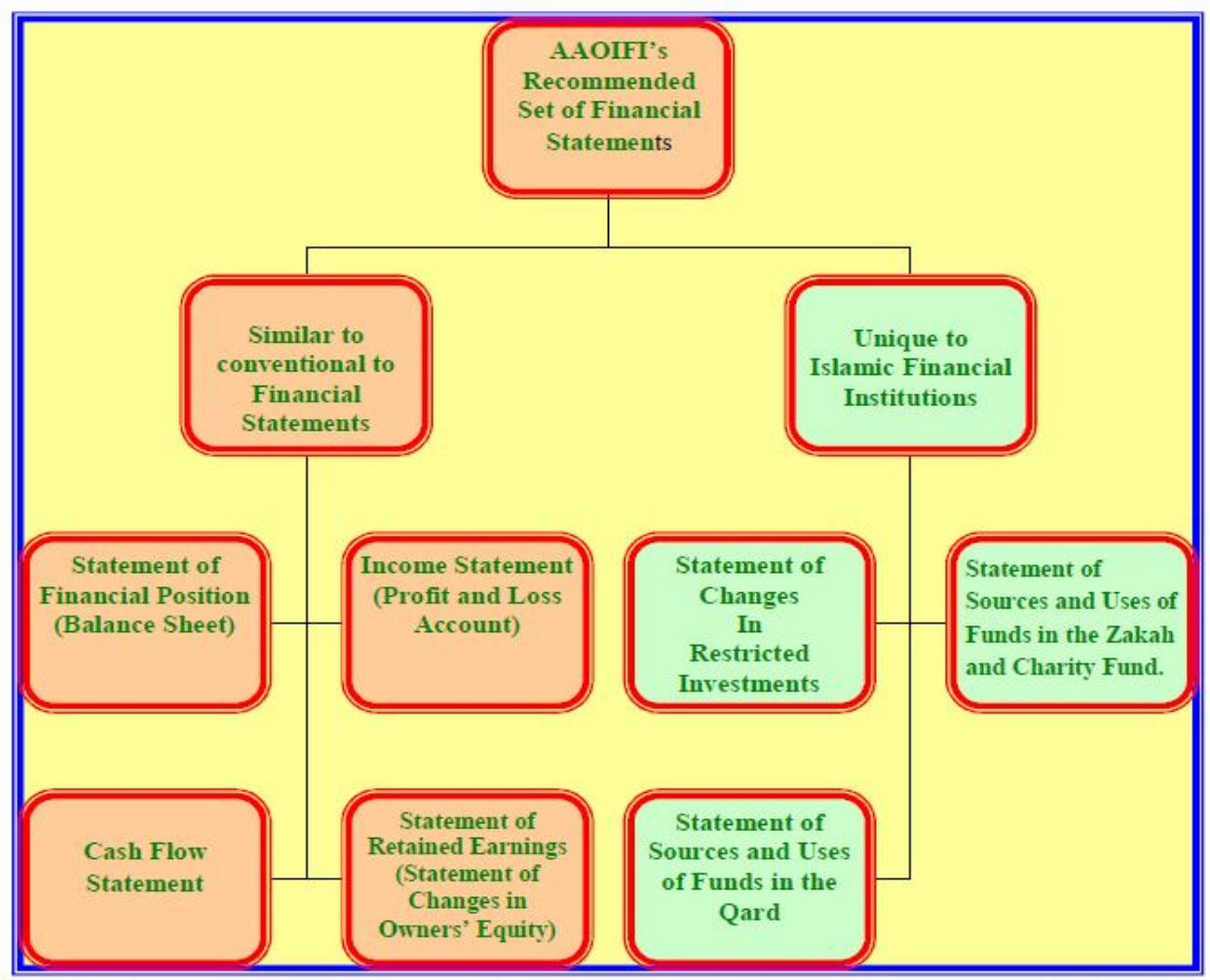

\section{3- The major users of financial reports of Islamic Banking}

They are two types of accounting information users, as follow:

Internal Users; such as:

Top Management.

Executive Managers.

Employees.

Workers.

External Users; such as:

* Shareholders.

Investors.

Stock of Exchange. 
* Suppliers.

* Banks.

Clients.

Governmental Units.

Financial Analysts.

* Taxation Establishment.

* Consultants.

*egal Accountants.

* Researchers.

As with conventional banks, we have to consider the users of the financial reports of Islamic banking. The users include equity holders, current and savings account holders, regulatory agencies such as the Central Bank, other depositors and other who transact business with the bank. However, special classes of users of Islamic banking are investment account holders and Zakat agencies. However, even though there are common user groups such as equity holders, the uses and thus type of information the users of financial accounting information of Islamic banking are different from those of conventional banks.

Figure 4: The major users of accounting information of Islamic Banking 


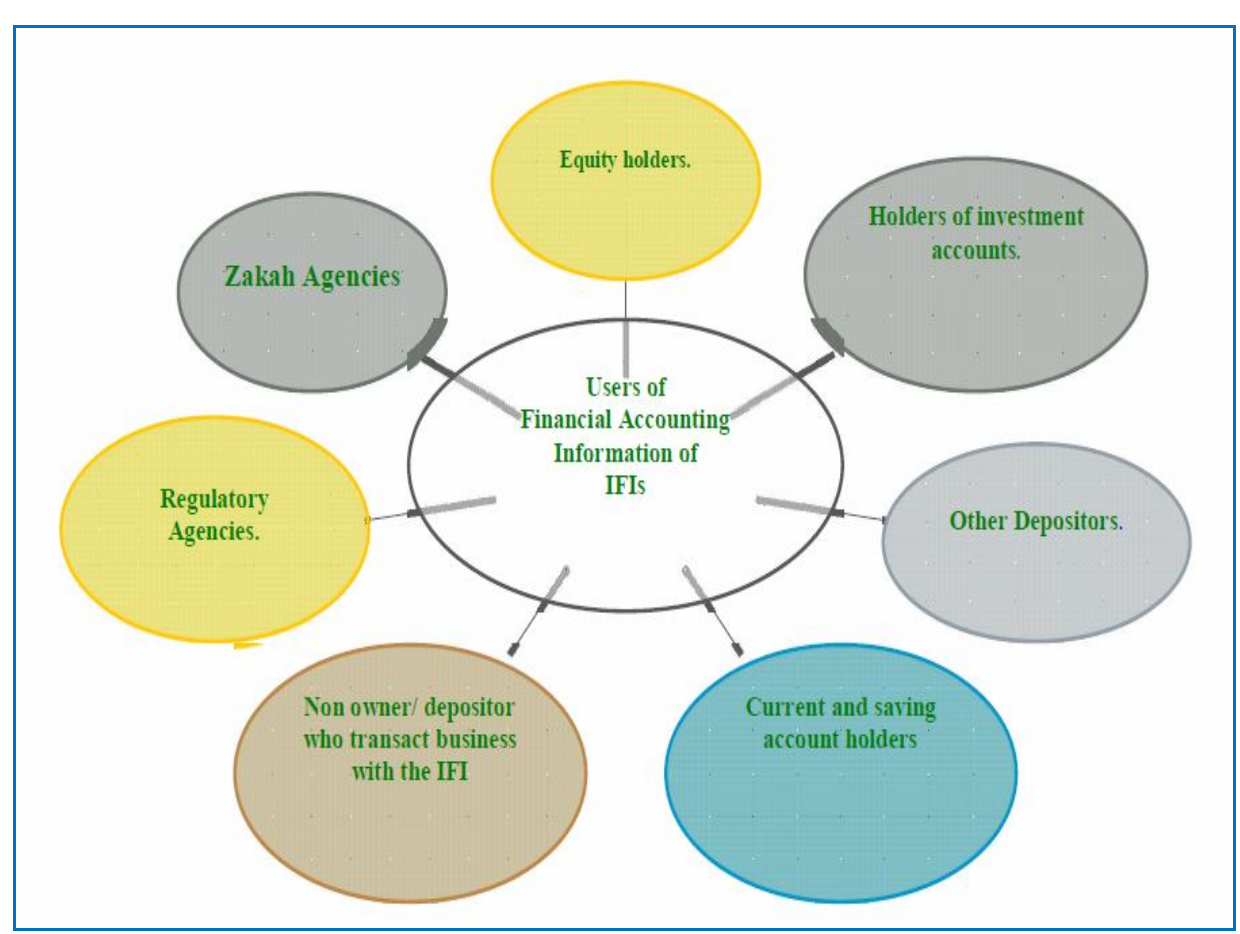

\section{Conclusion}

The need for Islamic accounting that deals with Islamic banking has prompted AAOIFI to introduce Financial Accounting Standards. The need for a codified Islamic accounting standard are primarily stemmed from the need that Islamic accounting objectives, concepts and principles to be developed based on sharia requirements. However, the Islamic accounting regulation also needs to adapt to the modern accounting regulatory environment to make it relevant to be practiced in our time.

AAOIFI's Standards point out four main functions of Islamic banking which are:

\section{Investment Management.}

Investment.

Financial services. 


\section{Social Services.}

Accordingly, the set of financial statements of Islamic banking consist of the following:

* Financial statements reflecting the Islamic Bank's function as an investor and its rights and obligation regardless of the objective of investment whether it is profit oriented or socially oriented. Such financial statements include:

* Statement of financial position.

* Statement of income.

* Statement of cash flow.

Statement of retained earnings or statement of changes in owners' equity.

* A financial statement reflecting changes in restricted investments managed by the Islamic bank for the benefit of others, whether based on Mudaraba contract or agency contract.

$\not$ Financial statements reflecting the Islamic bank's role as a fiduciary of funds made available for social purposes when such services are provided through separate funds:

Statement of sources and uses of Zakat and Charity fund.

Statement of sources and uses of funds in the Qard fund.

To sum up, the AAOIFI accounting standards for Islamic Financial Institutions are the best choice for increasing the investments and investor's confidence among Islamic banking. 


\section{References}

1. AAOIFI, Accounting and Auditing Standards for Islamic Financial Institutions, Manama, Bahrain, 2007.

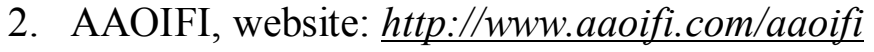

3. Choi, F. D.S. \& Mueller, G. G., International Accounting, New York: Prentice-Hall International Inc, $2^{\text {nd }}$ Edition, 1992, pp. 57; 65.

4. Eltigani Abdulqadir Ahmed, Accounting Postulates and Principles from an Islamic Perspective, Review of Islamic Economics, Vol. 3, No.2, 1994, pp. 1- 18.

5. Hamat, M., Accounting System; Need for Accounting Standards and the Implications of Islamic Banking on Current Tax Laws. Conference of Managing and Implementing Dual Banking System, Kuala Lumpur, 1994.

6. Hussien Shehata, Islamic Accounting Methodology, Website: $\underline{w w w . d a r e l m a s h o r a . c o m}$

7. Karim, R.A.A, International Accounting Harmonization, Banking Regulation and Islamic Banks.

8. Karim, R.A.A, The Nature and Rationale of a Conceptual framework for Financial Reporting by Islamic Banks, Accounting and Business Research, 25 (100), 1995, pp. 285-300.

9. Mirza, A.M. \& Baydoun, N., Accounting Policy Choice in a Ribafree Environment, Accounting, Commerce \& Finance: The Islamic Perspective Journal, Vol.4, Nos.1 \& 2, 2000, pp. 30- 47.

10. Muhammad Amanullah Khan, Contemporary Accounting Practices and Islamic Banking, Review of Islamic Economics, Vol. 3, No. 1, 1994, pp. 51-61

11. Muhammed F. Bahjatt, Towards Standards for Religious Audit in Islamic Banks, Review of Islamic Economics, Vol. 3 , No.2, 1994, Arabic section, pp. 1- 60 . 
12. Pendlebury, M. \& Naser, K., The Influence of Islam on Bank Financial Reporting, International Journal of Commerce \&Management, 7 (2), 1997, pp. 56-83.

13. Samer Kantakji, Islamic Accountancy Fiqh, Dar Arrissala, 2004, Website: www.kantakji.org

14. Seif I. Tag El-Din, Issues in Accounting Standards For Islamic Financial Institutions, Markfield Institute of Higher Education, September 2004.

15. Shahul Hameed bin Mohamed Ibrahim, Islamic Accounting - A New Push, Akauntan Nasional, Jan-Feb 2003. 